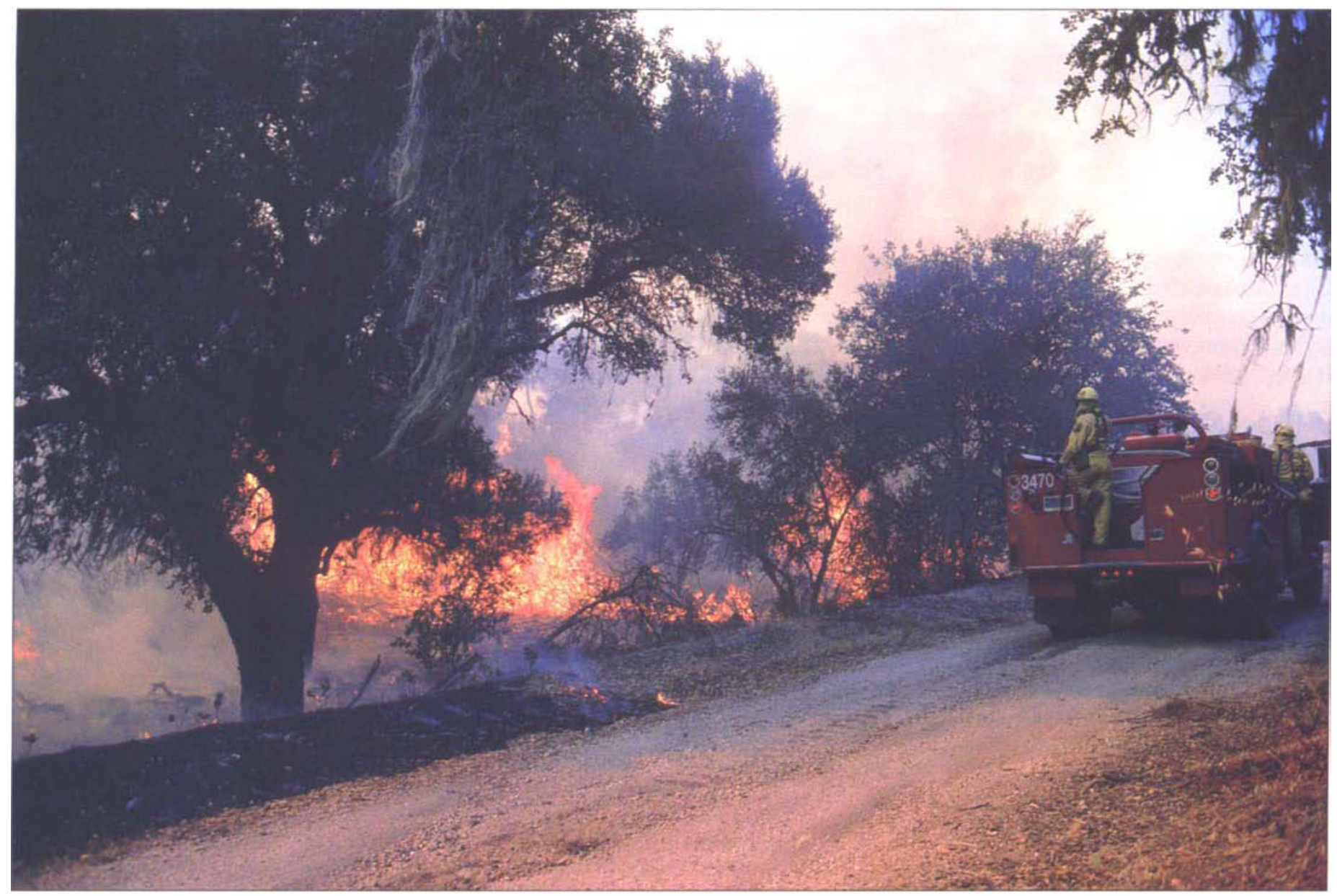

In October 1997, CDF and the Camp Roberts Fire Department experimentally burned 50C acres of oak woodland. Researchers evaluated the effects of the prescribed burn on blue oak and coast live oak saplings.

\title{
Live oak saplings survive prescribed fire and sprout
}

\author{
William D. Tietje 」 Justin K. Vreeland J William H. Weitkamp
}

\begin{abstract}
Sapling surveys conducted before and after a prescribed fire in an oak woodland revealed that approximately half of marked blue oak and coast live oak saplings were top-killed (aboveground tissue of sapling killed) by the fire. Most top-killed saplings sprouted, and sprout growth was strong within one growing season. Lightintensity prescribed fires probably have little effect on overall sapling survival and recruitment, and may benefit individual saplings by reducing competition and recycling nutrients.
\end{abstract}

$\mathrm{O}$ ak-dominated woodlands occur over approximately 7.4 million acres of California. Native Americans relied on oaks as a primary source of food in the form of acorns and, indirectly, for the habitat that the woodlands provided for game animals. Evidence indicates that some Native Americans intentionally burned woodlands to clear ground, aid in gathering acorns and drive game (as cited in Rossi 1980).

Today, most of the state's oak woodlands are privately owned and used primarily for livestock production. During recent decades, fire suppression has been a dominant policy, leading to heavy fuel loads in oak woodlands in some areas. At the same time, residential development in oak woodlands has increased dramatically This combination has increased the occurrence and intensity of wildfires in oak woodlands, which in turn has raised public interest in the use of prescribed burning to limit fuel accumulation. Use of prescribed burning is also a common management practice for forage and shrub management on oak rangelands. The California Fire Plan-A Framezork for Minimizing Costs and Losses from Wildland Fires (CDF 1996) outlines increased use of prescribed burning in oak woodlands, both to limit fuel buildup and the se- 
verity of wildfires and as a management tool for livestock production. The California Department of Forestry and Fire Protection (CDF) annually conducts prescribed fires over 2,000 to 8,000 acres of oak woodland on California's Central Coast.

Fire in woodlands affects vegetation composition and structure. Although many studies have investigated the effects of fire on forage production, few studies have evaluated its effects on the survival and growth of oak saplings (Lathrop and Osborne 1991; Schwan et al. 1997). Our purpose was to document survival and growth of blue oak (Quercus douglasii) and coast live oak $(Q$. agrifolia) saplings after experimental prescribed burning in a coastal-central California oak woodland.

We conducted this study at Camp Roberts, a military facility of the California Army National Guard in northern San Luis Obispo County and southern Monterey County, about 11 miles $(18 \mathrm{~km})$ north of Paso Robles (fig. 1). The facility includes 44,000 acres, of which approximately 18,000 acres is oak woodland. The dominant overstory tree is blue oak, with a variable contribution of coast live oak. Where it occurs, understory is dominated by toyon (Heteromeles arbutifolia), redberry (Rhamnus crocea), bigberry manzanita (Arctostaphylos glauca), ceanothus (Ceanothus spp.) and poison oak (Toxicodendron diversilobum). On the woodland floor, wild oats (Avena spp.), bromes (Bromus spp.) and fescues (Festuca spp.) dominate. Mean annual temperature is $59.5^{\circ} \mathrm{F}\left(15.3^{\circ} \mathrm{C}\right)$; total annual precipitation averages approximately 15.0 inches $(38 \mathrm{~cm})$. Most of our study area receives minimal use by military personnel and is not managed specifically for livestock, woodcutting or other land-use activities. Sheep grazing is conducted on Camp Roberts each spring.

\section{Prefire field measurements}

We marked saplings on four study plots that we had established in 1993 for another study (figs. 1 and 2). The study plots were gridded on an alphanumeric grid with 49.2-foot (15-meter)

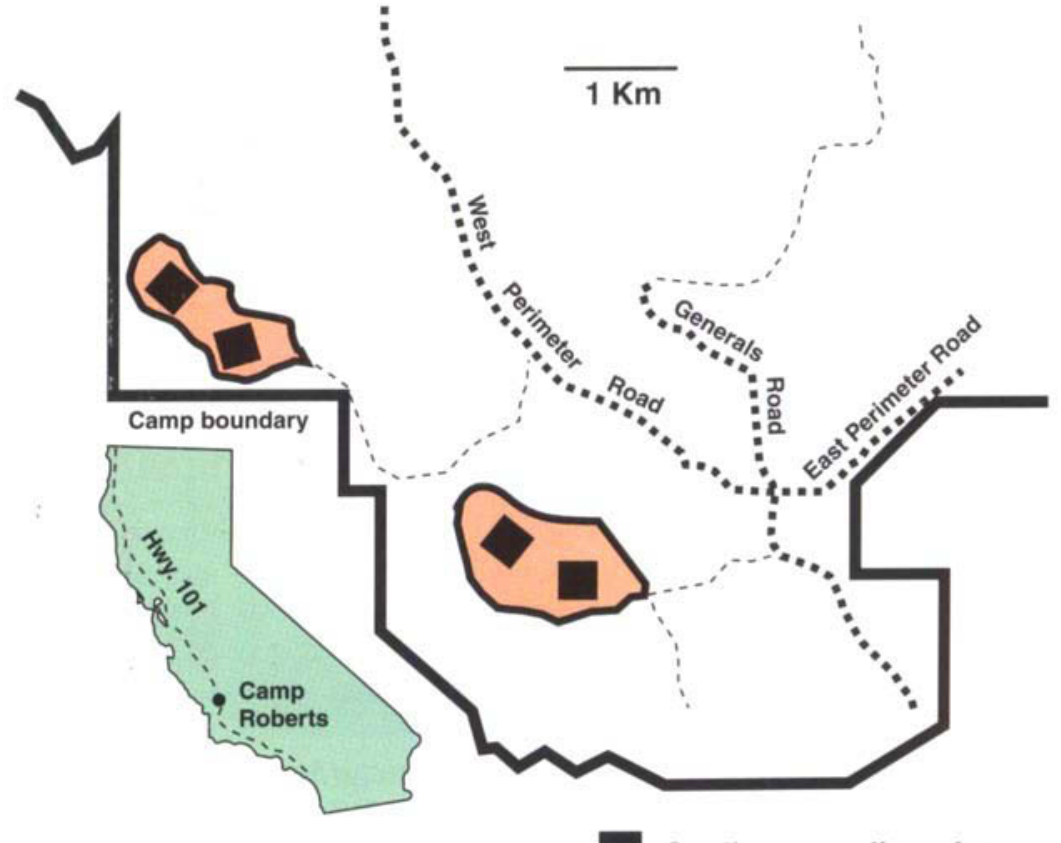

Sapling sampling plot

Fig. 1. Camp Roberts study area showing location of four 14.3-acre (5.8 ha) plots used to assess the response of blue oak and coast live oak saplings to prescribed burning in oak woodlands, Camp Roberts, 1997-1998.

intersections. The four plots were within two areas that were scheduled for burning. In September 1997, prior to the prescribed fires, two field-workers walked parallel to one another, one on either side of the $C, G, K$ and $O$ grid lines of the four study plots. We wired a numbered aluminum tag to blue oak and coast live oak saplings that we visually located between transect lines A and E, E and I, and so on (fig. 2). Saplings were defined as having a 12-to84-inch (31-to-213 cm) total stem length (that is, stems $<12$ inches or $>84$ inches were not used). Because saplings tended to be clumped and we wanted the tagged saplings to be independent samples, we applied the arbitrary criterion that any two tagged saplings of the same species had to be $>2$ grid intersections apart $(98.4$ feet; 30 meters).

The length (nearest 1 inch) of each of the tagged saplings was measured with a retractable logger's tape held along the stem from ground level to the end of the longest stem. The amount of fuel within 3.3 feet $(1 \mathrm{~m})$ of the sapling was assessed (fuel index)

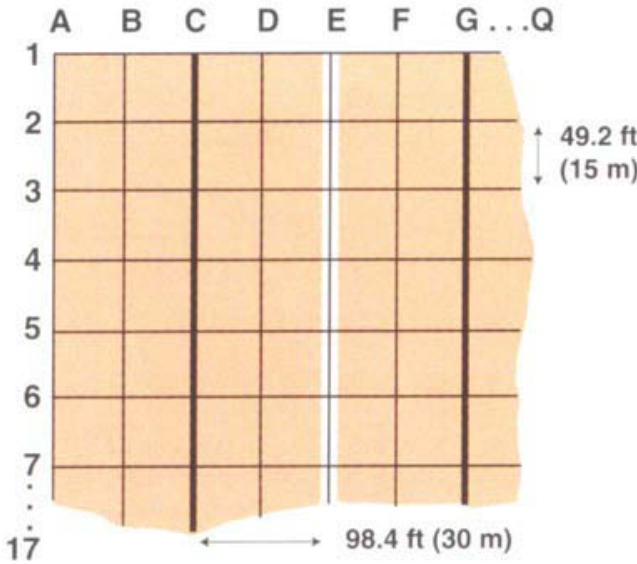

Fig. 2. Grid layout and transect lines on one of four 14.3-acre (5.8 ha) plots used to locate blue oak and coast live oak saplings during September 1997 at Camp Roberts. Two field-workers walked approximately parallel on either side of the $C, G, K$, and $O$ lines and located saplings within 98.4 feet $(30 \mathrm{~m})(2$ grid intersections) of these lines. Saplings tagged for monitoring were $>98.4$ feet apart.

by assigning one of the following categories:

- Light: Only bare soil, rock, leaves and grasses.

- Medium: At least some woody material $\leq 0.5$ inches diameter and $\geq 12$ inches in length.

- Heavy: At least some woody material $>0.5$ inches diameter and $\geq 12$ inches in length. 
TABLE 1. CDF fire intensity scale used to assess a prescribed fire in October 1997, Camp Roberts

\begin{tabular}{|c|c|c|c|}
\hline \multirow[b]{2}{*}{ Property } & \multicolumn{3}{|c|}{ Intensity } \\
\hline & Low & Medium & High \\
\hline Litter or duff & $\begin{array}{l}\text { Majority of duff layer is } \\
\text { unburned or only } \\
\text { slightly scorched. }\end{array}$ & $\begin{array}{l}\text { Duff consists of partially } \\
\text { burned or charred pieces } \\
\text { of twigs, leaves and so } \\
\text { on, and is still intact on } \\
\text { the surface and } \\
\text { recognizable. }\end{array}$ & $\begin{array}{l}\text { Most or all of the original } \\
\text { duff has been burned to } \\
\text { powdered ash (either black } \\
\text { or white) with no } \\
\text { recognizable charred pieces } \\
\text { or organic residue. }\end{array}$ \\
\hline Brush canopy & $\begin{array}{l}\text { Brush canopy is mostly } \\
\text { unburned or leaves intact } \\
\text { but may be highly } \\
\text { scorched and will probably } \\
\text { fall to the ground; } 0 \% \text { to } \\
30 \% \text { cover removed. }\end{array}$ & $\begin{array}{l}\text { Most leaves have been } \\
\text { burned off limbs, but many } \\
\text { skeleton limbs and branch- } \\
\text { ing above ground surface; } \\
30 \% \text { to } 70 \% \text { cover removed. }\end{array}$ & $\begin{array}{l}\text { Both leaves and skeleton } \\
\text { have been burned off. } \\
\text { Surface consists mostly of } \\
\text { burned stumps a few inches } \\
\text { above ground; } 70 \% \text { to } 100 \% \\
\text { cover removed. }\end{array}$ \\
\hline $\begin{array}{l}\text { Soil surface } \\
\text { condition }\end{array}$ & $\begin{array}{l}\text { No visible heating effects } \\
\text { observed on surface. } \\
\text { Soil structure has not } \\
\text { been altered and surface } \\
\text { remains open and porous. }\end{array}$ & $\begin{array}{l}\text { Some thin or brittle surface } \\
\text { crusting ( }<1 \mathrm{~cm} ; 0.4 \text { inch) present } \\
\text { but not continuous. Some } \\
\text { degree of reduced infiltration } \\
\text { expected in patchy areas only. }\end{array}$ & $\begin{array}{l}\text { Surface has extensive baked } \\
\text { crust condition or "fire brick" } \\
\text { appearance. Significant } \\
\text { reduction in infiltration and } \\
\text { porosity. }\end{array}$ \\
\hline
\end{tabular}

TABLE 2. Vegetative characteristics of four 14.3 acre (5.8 ha) plots on which 63 blue oak and 42 coast live oak saplings were sampled to assess effects of a prescribed fire in October 1997. Camp Roberts*

\begin{tabular}{lrr}
\hline $\begin{array}{l}\text { Vegetation } \\
\text { characteristic }\end{array}$ & Average & SD \\
\hline Live tree† density (no./acre) & 116.2 & 25.1 \\
Live tree DBH (inches) & 7.9 & 0.6 \\
Live tree height (feet) & 20.5 & 1.2 \\
Canopy cover $(\%)$ & 63.9 & 6.4 \\
Shrub cover $(\%)$ & 20.7 & 11.6 \\
Grass cover $(\%)$ & 45.2 & 5.4 \\
Litter cover $(\%)$ & 36.0 & 2.3 \\
Coarse woody debris cover $(\%)$ & 4.4 & 1.4 \\
\hline
\end{tabular}

'Data adapted from Tietje and Vreeland (1997) and Tietje et al. (1997).

† Live tree $=$ living trees $\geq 2$ inches $\mathrm{DBH}$.

$\ddagger \mathrm{DBH}=$ diameter at breast height, 4.5 feet

aboveground on the uphill side of a tree.

TABLE 3. Preburn characteristics of oak saplings subjected to a prescribed fire in October 1997, Camp Roberts

\begin{tabular}{lcc}
\multicolumn{3}{c}{ October 1997, Camp Roberts } \\
\hline \hline Characteristics & Blue oak & $\begin{array}{c}\text { Coast } \\
\text { live oak }\end{array}$ \\
\hline Trees tagged & 63 & 42 \\
Stem length (inches) & & \\
Average & 40.4 & 55.1 \\
Standard error & 2.2 & 3.6 \\
Minimum & 17.2 & 17.2 \\
Maximum & 80.0 & 84.0 \\
Fuel load index (trees) & & \\
Light & 31 & 13 \\
Medium & 23 & 20 \\
Heavy & 9 & 9 \\
\hline
\end{tabular}

\section{Postfire field measurements}

On Oct. 7 and 8, 1997, CDF and the Camp Roberts Fire Department conducted a prescribed burn over a 180 acre (73 ha) block of oak woodland and another of 320 acres (130 ha) (fig. 1). Each block contained two of the four study plots. A burned perimeter was established and drip torches were used to ignite the interior of the burn blocks. We used two methods to assess area burned and fire intensity. First, during the burns, we noted flame heights, approximate speed of the fire, and types and locations of vegetation affected by the fire. Later we applied this information to the CDF fire index, which uses these criteria to classify fire intensity as low, medium or high (table 1). Second, to obtain a more quantitative estimate of the area burned, we recorded whether burning had occurred within 3.3 feet of each of 64 grid intersections on eleven 2.5-acre (1 ha) small-mammal trapping grids that had been established within the burned areas for another study.

Initial visit to tagged saplings. During November and December 1997, and January 1998, within 3 months of the prescribed fire, we measured the distance from the sapling within which burning had occurred ( $\leq 3.3$ feet [ 1 meter], 3.3 to 16.4 feet [ 1 to 5 meters] or $>16.4$ feet [ $5+$ meters]), and the presence of scorching or char-

One-year visit to tagged saplings. In September 1998, following the first growing season after the fire, we revisited the marked saplings and observed the status of the sapling (alive or dead), measured its length, counted the number of sprouts and measured the length of the tallest sprout.

\section{Vegetation and sapling traits}

We used the log-likelihood ratio, $G$, to determine the proportion of sapring of the stem and leaves. lings surviving and sprouting between species and among fuel load categories (Light, Medium or Heavy). Tests were significant at $P \leq 0.05$.

Tree density, canopy cover and shrub cover were high in the stands in which we sampled oak saplings (table 2 ). Grass covered approximately half of the plots, and litter covered approximately one-third. Coarse woody debris cover, a partial index of fuel load, was approximately $4 \%$.

A total of 105 saplings were tagged, 63 blue oak and 42 coast live oak (table 3 ). The average height of blue oak saplings when tagged was 40.4 inches ( \pm 2.2 inches SE [standard error]; range $=17$ to 80 inches) (table 3 ). Coast live oak saplings averaged 55.1 inches ( \pm 3.6 inches SE; range $=17$ to 84 inches). Overall, fuel load was Light for 44 saplings, Medium for 43 saplings and Heavy for 18 saplings (table 3 ).

\section{Fire intensity}

Flame length was usually 3 feet or less. Except for the area around some larger logs that burned and some burned woodrat (Neotoma fuscipes) houses, almost no visible heating effects were observed on the soil surface, and mineral soil was mostly unexposed (table 1). Most areas were burned over where heavy grass cover occurred. Duff and leaf litter under a heavy canopy of coast live oak was either unburned or consisted of partially burned or charred pieces of twigs and leaves, mostly intact and recognizable (table 1). Shrub canopy and tree canopy were almost entirely unburned, and scorching of shrub and tree leaves and stems was infrequent and generally limited to the lower leaves and stems. Fire reached the crown of only a few mature trees.

CDF's fire intensity rating scale of low, medium and high placed this level of burning in the low-to-medium range. The fire burned to within an average of $46 \%$ of the 64 grid intersections of the eleven 2.5-acre smallmammal trapping plots (range $=30 \%$ to $66 \%$ ). Based on this measure and our visual estimates, the prescribed fire burned over approximately half (250 acres) of the treatment area (500 acres). 


\section{Survival and sprouting rates}

Initial visit. We did not include one of the tagged saplings in the analyses because the distance to which burning occurred was not recorded. We were also unable to relocate three saplings. We assume that these saplings were consumed by the fire, but we do not treat them as such and therefore do not include them in the analyses. Our postfire survey of the tagged saplings revealed that the prescribed fire burned within 3.3 feet, between 3.3 and 16.4 feet, and beyond 16.4 feet at 57,19 and 25 , respectively, of the remaining 101 saplings. We detected effects of the prescribed fire on only those 57 saplings at which burning occurred within 3.3 feet. Hereafter, our results are based on only the 57 saplings affected by the fire.

At least some leaves were burned on 52 of the 57 affected saplings, and some leaves were burned off of 19 . The main sapling stem was burned (scorched or charred) on 43 of the affected saplings. Of those 43 , scorching occurred on 14 and charring on 29 . On 6 saplings, the main stem was completely consumed, or the remaining stem was separated from the root wad.

\section{Sapling survival at 1-year} postfire. Of 56 affected saplings for which survival data was available (survival data was missing for one coast live oak sapling), 42 were topkilled by the fire. (Saplings are topkilled when the aboveground stem is killed.) Survival was proportionally similar $(P=1.000)$ between blue oak (10 alive of 38 ) and coast live oak (4 alive of 18) saplings (fig. 3A). Survival was better for saplings at which the fuel load within 3.3 feet was lighter $(P$ $=0.040$ ) (fig. 3B). Only 2 of 44 saplings apparently unaffected by the fire (that is, where burning occurred beyond 3.3 feet) were dead at the time of the 1year postfire visit. Six saplings were either totally consumed or had their stems burned through by the fire. Three of these did not sprout, and we assume that heat from the fire was intense enough to kill the root system. Height of saplings was unrelated to survival: saplings killed by fire $(\mathrm{n}=$ 42) averaged 45.6 inches tall $( \pm 3.3$ inches SE); saplings alive 1 year after the fire $(n=14)$ averaged 43.3 inches tall $( \pm 5.5$ inches SE).

Sapling sprouting at 1-year postfire. Of 55 affected saplings for which sprouting data were available (sprouting data were missing for 1 blue oak and 1 coast live oak), 36 sprouted. The number of blue oak saplings sprouting (26 sprouting of 37) was proportionally similar to the number of coast live oak saplings sprouting (10 sprouting of $18 ; P=0.442$ ) (fig. $3 \mathrm{~A})$. Percent of saplings sprouting was similar among Light, Medium and Heavy fuel loads ( $P=0.745)$ (fig. 3B). One of the unaffected saplings sprouted for reasons apparently unrelated to the fire.

Average number of sprouts per affected sapling was 15.8 ( $\pm 1.4 \mathrm{SE}$ ) on blue oak and 6.4 ( $\pm 1.2 \mathrm{SE})$ on coast live oak. Average length of the longest sprout was 24.8 ( \pm 1.7 inches $\mathrm{SE}$ ) inches for blue oak and 24.1 ( \pm 4.1 inches SE) inches for coast live oak. Sprouts of affected saplings $(n=57)$ averaged $61.4 \%$ ( $\pm 31.8 \%$ SD [standard deviation]) of the height of the prefire sapling stem.

\section{Saplings survive fire by sprouting}

If the prescribed fire burned in the immediate vicinity of the sapling, chances were high that it was topkilled. The factor that predisposed a sapling to damage was simply if there was enough fuel to carry the fire to the sapling; the fire burned on approximately half the area treated with prescribed fire (500 acres), and about half of the saplings in the treated areas were affected by the fire. Any visually detectable effect of the fire, including leaves scorched or burned off, or scorching or charring of the stem, usually resulted in top-killing. The woodland we studied had a high fuel load composed mostly of duff, coarse woody debris and shrubbery; however, oak woodlands with a grassy understory, but with little shrubbery and coarse woody material, may experience similar sapling mortality rates.

Coast live oak saplings and blue oak saplings were affected similarly by the fire. This contrasts with fire effects on mature trees of these species. Studies of mature oaks indicate that coast live oak trees are extremely fire resistant, while blue oak is relatively sensitive to fire because of its comparatively thin, dry and flaky bark. On saplings of coast live oak that are less than 7 feet in length (the maximum size monitored in this study), the bark has not yet attained the characteristics (thickness, composition, chemicals) that render fire resistance.

Although approximately half of the 101 monitored saplings were topkilled, biologically the sapling is dead only if it does not sprout. All but 3 of the top-killed saplings sprouted, and within 1 year reached an average height of nearly two-thirds of their prefire length. During wildfires, weather conditions are usually such that fire temperatures are hotter and the potential for completely killing saplings is much greater than during most prescribed fires, which are usually of light to moderate intensity. In 1992, a wildfire burned 500 acres of rural land owned by Stanford University

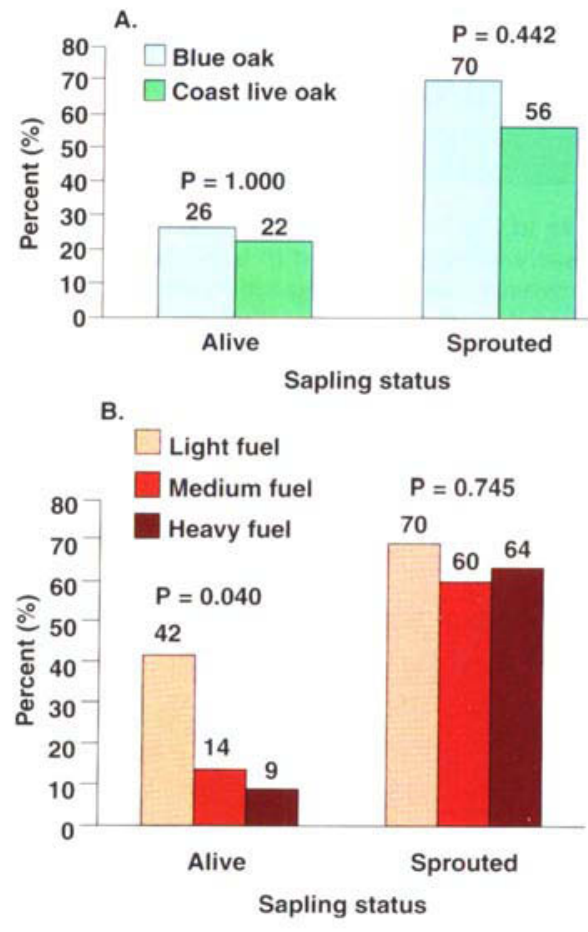

Fig. 3. Survival and sprouting response of blue oak and coast live oak saplings at which prescribed fire burned to within 3.3 feet ( $1 \mathrm{~m} ; n=57$ ), Camp Roberts, October 1997. P-values are the result of loglikelihood tests conducted on survival and sprouting response within $(A)$ sapling species and (B) fuel load. Results are significant at $P \leq 0.05$. 


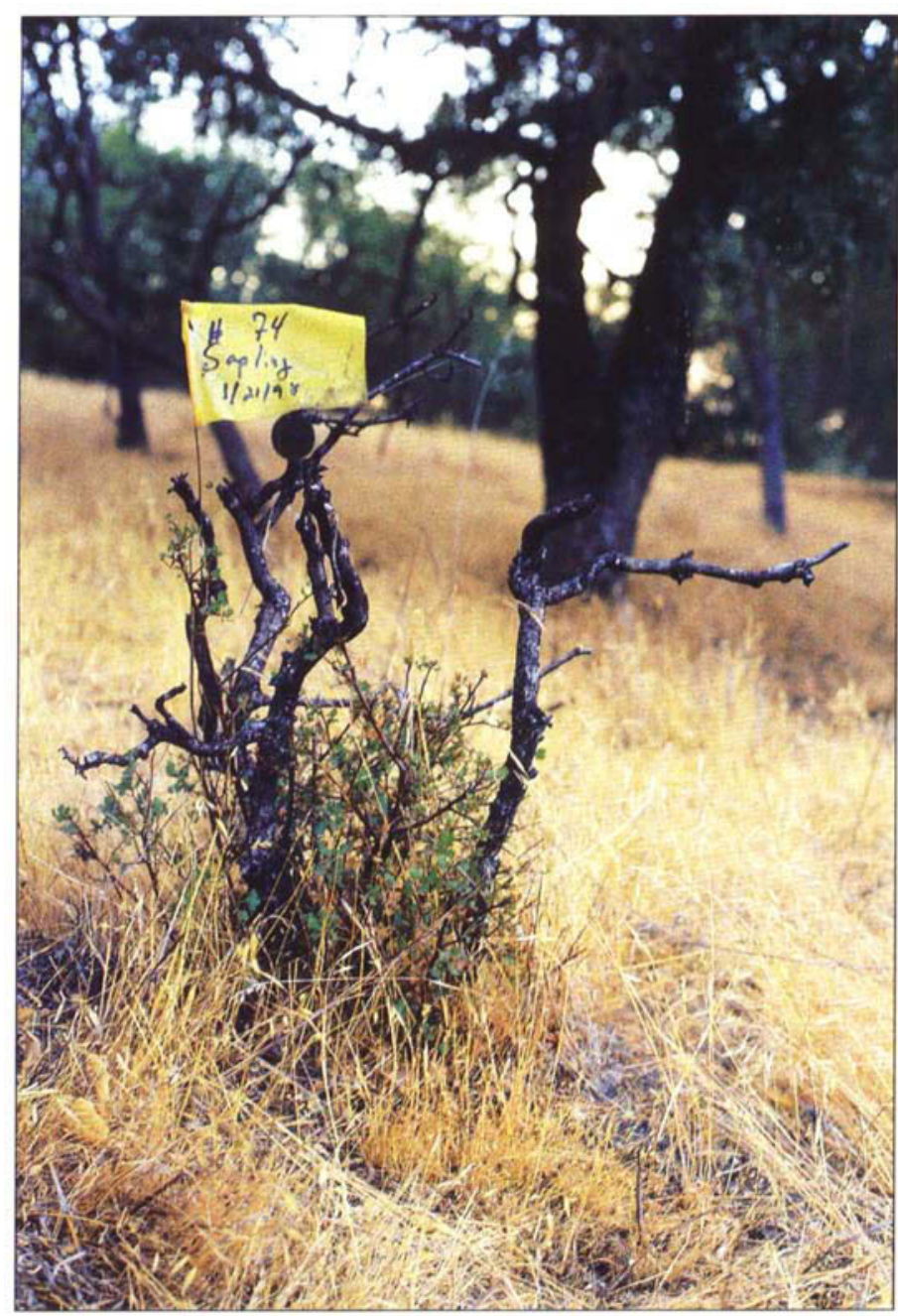

Fire in the immediate vicinity of a sapling nearly always resulted in top-killing; however, nearly all top-killed saplings sprouted. One year postfire, sprouts averaged approximately two-thirds the length of the prefire sapling stem.

(Schwan et al. 1997). More than 550 juvenile oaks (that is, oaks $<10$ feet tall) had been marked before the wildfire. Only $22 \%$ of the juvenile oaks were top-killed and $17 \%$ were completely killed by the wildlife, compared to $40 \%$ top-killed and 3\% completely killed by the prescribed fire in this study. Another study looked at the effects of a wildfire and two prescription burns that burned Engelmann oak $(Q$. engelmannii) woodland on the Santa Rosa Plateau, Riverside County, in 1988 and 1989 (Lathrop and Osborne 1991). The wildfire top-killed over $75 \%$ of the monitored seedlings and saplings. However, two-thirds of the topkilled oaks had sprouted by the following May. Details of the structure and fuel load of the oak woodlands that burned were not given.

\section{Management guidelines}

Light-intensity fires apparently do not harm the sapling crop. Furthermore, they reduce competition from other vegetation (especially annual grasses), recycle nutrients sequestered in dead organic material and reduce the risk of catastrophic fire. Frequent, lightintensity fires may therefore promote sapling establishment, at least in well-structured blue oak and coast live oak woodlands.

Fire timing may play an important role in sapling survival. We conducted our prescribed fire in early fall. Fires in spring, when new leaves are produced by (deciduous) saplings, may injure saplings more. In addition, steam-heating effects may occur if moisture in fuels is high enough. Conversely, spring fires may remove more competing annual grasses than fall fires because grass seeds are burned before they mature.

Ranchers who want to promote sapling regeneration on rangelands may want to protect saplings from high fuel loads. Brush piles can improve sapling survival by preventing cattle grazing on young saplings. However, burning to improve livestock forage could damage saplings if existing or planted saplings are protected by brush piles (see p. 23). Brush piles can be constructed in donut shapes to minimize heating effect directly on saplings. In some areas, removing heavy fuels (logs, stumps, branches, dense grass) from around saplings could prevent topkilling of saplings.

W.D. Tietje is Natural Resource Specialist, Department of Environmental Science, Policy and Management, UC Berkeley; J.K. Vreeland was Staff Research Associate and W.H. Weitkamp is Livestock and Natural Resource Advisor Emeritus, UCCE San Luis Obispo County. Vreeland is currently Master's Candidate, Penn State.

The authors thank the Army National Guard, Camp Roberts Fire Department and California Department of Forestry and Fire Protection. This study was supported by the UC Integrated Hardwood Range Management Program, CDF Grant 8CA96037 and UCCE San Luis Obispo County.

\section{References}

[CDF] California Department of Forestry and Fire Protection. 1996. California fire plan-A framework for minimizing costs and losses from wildland fires. Report to California Board of Forestry, Sacramento CA. $104 \mathrm{p}$.

Lathrop EW, Osborne CD. 1991. Influence of fire on oak seedlings and saplings in southern oak woodland in the Santa Rosa Plateau Preserve, Riverside County, CA. In: Standiford R (ed.). Proceedings of the Symposium on Oak Woodlands and Hardwood Rangeland Management. US Forest Service Genera Technical Report GTR-PSW-126:366-70.

Rossi RS. 1980. History of cultural influences on the distribution and reproduction of oaks in California. In: Plumb TR (ed.). Proceedings of the Symposium on the Ecology, Management and Utilization of California oaks. US Forest Service General Technical Report GTR-PSW44:7-18

Schwan J, Fong $\mathrm{H}$, Hug H. 1997. Wildfire and oak regeneration at the urban fringe. In: Pillsbury N, Verner J, Tietje WD (eds.). Proceedings of the Symposium on Oak Woodlands: Ecology, Management and Urban Interface Issues. US Forest Service General Technical Report GTRPSW-160:559-64.

Tietje WD, Vreeland JK. 1997. Vertebrates diverse and abundant in well-structured oak woodland. Cal Ag 51(6):8-14.

Tietje WD, Vreeland JK, Siepel NR Dockter JL. 1997. Relative abundance and habitat associations of vertebrates in oak woodlands in coastal-central California. In: Pillsbury N, Verner J, Tietje WD (eds.). Proceedings of the Symposium on Oak Woodlands: Ecology, Management and Urban Interface Issues. US Forest Service General Technical Report GTRPSW-160:391-400. 